\title{
Diskursus Sains dalam Kurikulum Pendidikan Agama Islam di Sekolah dan Madrasah Era Digital
}

\author{
Oleh: \\ Firman Mansir \\ Universitas Muhammadiyah Yogyakarta \\ firmanmansir@umy.ac.id
}

\begin{tabular}{l}
\hline Keywords: \\
\hline Islamic \\
Education; \\
Science; and \\
School
\end{tabular}

Kata kunci:

Pendidikan

Agama Islam;

Sains; dan

Sekolah

\begin{abstract}
The changes in curriculum and everything in between such as development of Islamic education, science, development innovation, change and others are inevitability which generate new challenges in the field. Facing this reality, all element of society expects that the role of Islamic religious education which indeed has taught moral and spiritual value. Therefore the urgency of Islamic religious education in providing teachings or guidelines for social activities becomes a very urgent need. In line with the statement, we need an educators who have creativity and innovation to be able to develop learning well and professionally. No matter how good the curriculum design is, if the delivery is not good, an effective learning will certainly not work. Scientific based learning implementation in Islamic education must be conducted to face dynamic things in educational world including the digital industry development.
\end{abstract}

\footnotetext{
Abstrak

Perubahan kurikulum dengan segala yang menyertainya antara lain perkembangan pendidikan agama Islam, sains, inovasi pengembangan, perubahan, dan lain sebagainya adalah sebuah keniscayaan yang melahirkan tantangan baru dalam bidang tersebut. Menghadapi kenyataan ini, seluruh elemen masyarakat berharap agar adanya peran pendidikan agama Islam yang memang di dalamnya telah mengajarkan nilai-nilai moral dan spiritual, oleh karena itu urgensi pendidikan agama Islam dalam memberikan ajaran ataupun pedoman untuk bersosial menjadi kebutuhan yang sangat mendesak. Sejalan dengan hal tersebut maka dibutuhkan seorang pendidik yang memiliki kreativitas dan inovasi agar mampu mengembangkan pembelajaran dengan baik dan profesional. Sebaik apapun desain kurikulumnya namun jika dalam penyampaiannya kurang baik, tentu pembelajaran yang efektif tidak akan berjalan. Implementasi pembelajaran yang berbasis pendekatan saintifik dalam
} 
kurikulum pendidikan agama Islam adalah sebuah hal yang harus dilakukan untuk menghadapi segala hal yang dinamis dalam dunia pendidikan termasuk diantaranya adalah perkembangan industri digital.

\section{Pendahuluan}

Secara statistik Indonesia merupakan salah satu negara terbesar di dunia yang penduduknya mayoritas menganut agama Islam. Dengan jumlah yang begitu banyak tidak serta merta bisa dijadikan kebanggaan bagi bangsa Indonesia. Hal ini menjadi problem yang akan sulit untuk rakyat Indonesia dimana potensi dan kemampuan dalam memecahkan persoalan dalam dunia pendidikan. Pendidikan merupakan hal yang paling wajib bagi setiap orang untuk kehidupannya dalam berbagai aspek, maka dari itu pendidikan harus senantiasa mengikuti perkembangan serta kemajuan peradaban (Watson, 2005). Seperti halnya pendidikan yang ada di Indonesia, masih mengalami ketertinggalan dari negara lainnya dalam hal persaingan di dunia pendidikan. Seharusnya negara Indonesia mampu berdampingan dengan negara-negara lainnya dalam hal kemajuan dunia pendidikan.

Upaya yang telah dilakukan oleh pemerintah melalui Kemendikbud dalam mempersiapkan bibit-bibit bangsa yang akan datang untuk berbenah dan mengembangkan kurikulum. Satu diantara pengembangan itu adalah yang berkaitan dengan kurikulum pendidikan agama Islam sesuai dengan kebutuhan dan tuntunan zaman melalui kurikulum 2013 yang diharapkan dapat menutupi kekurangan yang ada dalam kurikulum sebelumnya. Perubahan kurikulum dengan segala yang menyertainya antara lain perkembangan pendidikan agama Islam, sains, inovasi pengembangan, perubahan, dan lain sebagainya adalah sebuah keniscayaan yang melahirkan tantangan baru dalam bidang tersebut. Kondisi ini berangkat dari keadaan negara yang sangat krisis dalam berbagai dimensi kehidupan seperti ekonomi, politik, pendidikan, hukum dan lainnya. Akibat dari kondisi tersebut, maraknya kerusuhan sosial dimana-mana, semakin bertambahnya pembunuhan, unjuk rasa yang disertai dengan kerusuhan dan sebagainya.

Menghadapi keadaan ini, seluruh elemen masyarakat berharap agar adanya peran pendidikan agama Islam yang di dalamnya mengajarkan nilai-nilai moral dan spiritual, maka dari itu urgensi pendidikan agama Islam dalam memberikan ajaran ataupun pedoman dalam bersosial menjadi kebutuhan yang sangat mendesak. Disamping itu, pendidikan agama Islam diharapkan mampu menjadi fondasi dasar bagi pelajar 
khususnya bagi mereka yang mempelajari ilmu pengetahuan umum. Hal ini diharapkan dengan kehadiran mata pelajaran pendidikan Agama Islam, para siswa mampu berfikir dengan baik agar terbentuk manusia yang lebih baik pula dari sebelumnya dan tidak memisahkan antara kehidupan dunia dengan agama.

Islam adalah agama yang diturunkan kepada umat manusia dengan satu harapan besar yakni mampu membawa rahmat bagi alam semesta. Ajaran Islam senantiasa membawa kemaslahatan bagi kehidupan manusia di dunia Allah SWT sendiri telah menegaskan hal ini, sebagaimana termaktub dalam QS. Thaha (20) ayat 2.: "Kami tidak menurunkan al-Qur'an ini kapadamu supaya kamu menjadi susah." Artinya bahwa umat manusia yang mau diatur atau mengikuti petunjuk al-Qur'an, maka mendapat oleh Allah SWT bahwa kehidupan mereka akan bahagia dan sejahtera di dunia dan akhirat. Sebaliknya siapa saja yang tidak ikut aturan main atau membangkang dan mengingkari ajaran Islam, maka dengan serta merta akan mengalami kehidupan yang sempit dan penuh penderitaan.

\section{Metode}

Penelitian ini merupakan penelitian kualitatif yang bersifat studi pustaka (library research) yang penelitiannya menggunakan studi literaur maupun buku-buku sebagai objek yang paling utama. Jenis penelitian yang digunakan adalah penelitian kualitatif, yaitu jenis penelitian yang menghasilkan penemuan-penemuan dengan data yang bersifat deskriptif yang tidak dicapai dengan menggunakan prosedur-prosedur statistik (kuantitatif). Penelitian kualitatif ini, menggunakan metode analisis deskriptif yang memberikan keterangan dan gambaran secara jelas, objektif, sisitematis, analitis dan kritis mengenai kajian tentang pembelajaran sains yang diintegrasikan dengan pendidikan agama Islam melalui kajian-kajian ayat suci al-Qur'an yang diinterpretasikan dengan metode integratif. Pendekatan pada penelitian ini dilakukan dengan cara mengumpulkan bahan-bahan bacaan yang dibutukan dan yang relevan dengan tema penelitian. Setelah bahan-bahan bacaan itu dikumpulkan, langkah selanjutnya yaitu melakukan klarifikasi dan deskripsi terkait bahan bacaan.

\section{Hasil dan Pembahasan}

Pengertian sains berasal dari kata "science" artinya "to know", dan dapat diartikan sebagai ilmu. Secara istilah, sains adalah suatu pengetahuan dalam suatu bidang yang 
disusun secara sistematis dengan metode tertentu (Ismail, 2013). Kurikulum yang berasal dari bahasa Yunani yaitu " Curere" yang bermakna suatu jarak yang ditempuh, dan dalam dunia pendidikan kurikulum itu sebagai bahan atau suatu perangkat untuk menjalankan kegiatan dalam pendidikan. Dalam konteks pendidikan untuk mencapai suatu tujuan suatu pendidikan maka suatu kurikulum harus mempunyai metode maupun rancangannya untuk bisa berkembang (Saufi, 2019). Defenisi selanjutnya tentang sciense ialah suatu ilmu pengetahuan ilmiah yang menggabungkan dua pandangan filsafat yang salah satunya yaitu rasionalisme. Sedangkan pengertian sains secara istilah dan menurut para ahli sains dapat kita ketahui bahwasannya sains adalah suatu ilmu ataupun pengetahuan yang sudah tersusun secara sistematis dengan adanya beberapa aspek-aspek alam (Muspiroh, 2016).

Kualitas manusia sejatinya dapat dikategorikan menjadi tiga hal yakni: Pertama, berkenaan dengan kekuatan iman. Iman adalah keyakinan terhadap Allah, terhadap Malaikat-Nya, terhadap kitab-kitab-Nya, terhadap rasul-rasul-Nya, dan terhadap hari akhir. Di antara ayat al-Qur'an yang menyebutkan lima sendi iman tersebut adalah surat al-Baqarah ayat 177. Sedangkan iman kepada takdir Tuhan disebutkan dalam beberapa ayat al-Qur'an secara kontekstual, namun secara eksplisit terdapat dalam beberapa hadis nabi. Kemantapan iman yang kokoh dan benar merupakan penentu (barometer) nilai hidup manusia. Iman yang lurus bertumpu pada keyakinan tauhidullah, serta senantiasa mendorong untuk berbuat yang terbaik dalam hidupnya menuju ridha Allah SWT.

Kedua, berkaitan dengan kehendak untuk beramal saleh. Amal baik merupakan manifestasi dari iman yang benar. Amal saleh menuntut adanya ketaatan terhadap Allah, terhadap diri sendiri dengan berupaya memenuhi yang menjadi haknya (ruhani dan jasmani), terhadap keluarga dengan memenuhi yang menjadi haknya, terhadap tetangga dengan memenuhi apa yang menjadi hak tetangga, terhadap masyarakat dengan memenuhi apa yang menjadi hak masyarakat, dan seterusnya. Manusia adalah mahluk sosial yang saling memiliki hak dan kewajiban, plus solidaritas yang senantiasa ditumbuhkembangkan. Hidup tolong-menolong harus selalu ditegakkan dan senantiasa mendayung bersama pekerjaan yang dinilai memiliki dimensi untuk mengangkat kepentingan hidup bersama, tidak rakus, dan harus memelihara kelestarian lingkungan hidup (Sanusi Uwes, 2003).

Ketiga, berkenaan dengan ilmu pengetahuan. Untuk dapat merealisasikan amal saleh yang multidimensional itu, ilmu pengetahuan mutlak diperlukan sebagai sarananya. 
Dengan menggunakan pena, manusia dapat mencatat segala sesuatu yang dijumpai di alam raya ini. Alam raya merupakan kamus yang khusus diperuntukan kepada manusia. Bagi manusia yang berilmu, Allah berjanji akan mengangkat derajatnya. Ilmu memiliki nilai sentral di samping iman. Saking sentralnya masalah ilmu ini, sampai-sampai Nabi Muhammad SAW bersabda :"Barang siapa yang menghendaki dunia, hendaklah dengan ilmu, dan barang siapa yang menghendaki akhirat, hendaklah dengan ilmu, dan barang siapa yang menghendaki keduanya, hendaknya dengan ilmu." Dalam hal ini, keilmuan seseorang sangat berpengaruh dengan perilaku dan proses kehidupannya.

Berangkat dari desakan agar ilmu pengetahuan mampu menjawab setiap tantangan zaman yang datang silih berganti, maka perubahan kurikulum pada akhirnya adalah sebuah keniscayaan yang tidak dapat dihindarkan sekaligus efek dari adanya perkembangan internal dan eksternal yang dihadapi oleh masyarakat suatu bangsa dalam hal ini bangsa Indonesia (Mohamad Roji'i, 2019). Perubahan kurikulum 2013 ini terbagi menjadi empat elemen. Pertama; Standar Kompetensi Kelulusan (SKL) Kedua; Standar Isi (SI) Ketiga; Standar Proses (SP) Keempat; Standar Penilaian (SP). Dengan adanya keempat elemen tersebut bisa merubah arah proses pembelajaran yang dulunya hanya guru saja yang aktif tapinsekarang siswanya ditutut untuk bisa membentuk konsep dengan sendiri melalui pembelajaran yang integrative. Adapun ide yang dkelurkan oleh kurikulum 2013 tentang Pendidikan agama Islam mencoba memberikan perhatian yang sama dalam Pendidikan agama Islam dan Pendidikan umum, ibarat seorang penjelajah yang memegang teguh filosofi" sekali mendayung, satu dua pulau terlampaui” mungkin kiasan ini yang bisa disematkan dalam kurikulum 2013. Hal ini karena konsep kurikulum 2013 yang mengitegrasikan pelajaran kedalam standar kompetensi yang dimiliki masingmasing pelajaran. Dengan adanya model ini siswa harus bisa memahami konsep dasar yang utuh berdasarkan kehidupan nyata dan sekitarnya antara materi pembelajaran dan kehidupan yang ada untuk memberikan kekuatan antara keduanya (Munawar, 2005).

Selain itu perkembangan kurikulum yang mengalami keniscayaan sulit untuk bergulir dan yang ada terkesan memberi hambatan seiring berjalannya waktu, diantaranya bersumber dari tiga faktor yakni: pertama, perkembangan globalisasi, perkembangan era digitalisasi, dan kondisi yang memaksa. Dengan menghadapi perkembangan tersebut secara tidak langsung secara berkesinambungan akan menggerus nilai-nilai yang dimilik bangsa. Kedua, kompetensi masa depan, merupakan persaingan lokal maupun internasional untuk membutuhkan sumber daya manusia dalam menentukan kebijakan 
pendidikan. Ketiga, fenomena sosial yang menjadi alasan untuk perubahan kurikulum, dalam hal memegang teguh nilai-nilai religiusitas di dalam kehidupan sehari. Maka dari itu kurikulum 2013 merupakan keseimbangan dalam attitude (sikap), skill (kemampuan), dan knowledge (pengetahuan) (Faturrahman, 2016).

\section{Strategi Sains dan Kurikulum PAI dalam Pengembangan Pendidikan}

Strategi kurikulum dalam mencapai tujuan pendidikan adalah tidak lain harus mengembangkan dirinya dengan senantiasa mempertimbangkan suatu proses yang sedang berjalan sembari terus mengevaluasinya secara berkelanjutan (Respati, 2018). Dengan itu sains dan kurikulum PAI harus dievaluasi dan direkonstruksi dalam mengabungkan pembelajaran sains dengan kurikulum PAI, supaya dapat menyajikan outcome yang berkualitas (Supranoto, 2015). Sains yang secara garis beras mempunyai arti pengetahuan yang mana meliputi pengetahuan humanoria dan ilmiah. Dalam menggabungkan sains dengan kurikulum PAI yang dimana suatu pengetahuan ilmiah, humanoria dan agama harus berkaitan. Dan didalam sains sendiri harus terdapat filosofisnya, karena filsafat yang memandang sains secara komperehensif tidak ilmu yang berdiri sendiri. Seorang sains harus bisa memahami ilmu dengan disiplin karena setiap masalah di dalam sains tidak bisa diselesaikan dengan pendekatan sainst itu sendiri namun harus melibatkan pendekatan yang lain. Untuk itu dalam memahami semangat untuk saling menghargai keragaman pendapat sangatlah ditekankan (Ridlwan, 2013).

\section{Implementasi Integrasi Sains dan Agama dalam Pembelajaran Kurikulum PAI}

Dalam pengintegrasian mata pelajaran PAI dan Umum dapat dilakukan dengan dua cara meliputi:

a. Melalui pencarian dasar maupun konsep, dalam teori pembelajaran umum termasuk sains yang diambil dari Al Quran dan hadits dan juga pendapat dari beberapa ulama maupun ahli disitu hanya memasukan atau diisi dengan nilai-nilai Islami atau diberi landaasan dari Al Quran dan hadits karena untuk melegitimasi terhadap ilmu umum.

b. Mempelajari konsep dan teori pembelajaran umum kemudian dipadukan dengan pembelajaran kurikulum PAI (Mulyana, 2011).

Dalam implementasi pendekatan sains pada pembelajaran PAI harus dibangun atas dasar dan prinsip. Pada sisi lainnya harus dipahami bahwa setiap mata pelajaran yang akan dikembangkan tidak serta merta sesuai dengan akebutuhan penggunanya maka 
pendekatkan ilmiah harus digunakan agar mendekati kesempurnaan (Assegaf, 2010). Berikut ini adalah hal-hal yang harus diperhatikan dalam pembelajaran PAI yang terbagi menjadi beberapa material pembelajaran :

a. Pendekatan saintifik adalah langkah yang sistematis seperti seorang ahli ilmu yang mendapatkan jawaban obyektif dari pembelajaran.

b. Sangatlah penting dalam mengintegrasi tema yang kebenarannya bersifat dogmatis dan ilmiah.

c. Mendiskripsikan ulang tentang standard kompetensi yang ingin dicapai dalam pembelajaran.

d. Kreativitas dan inovasi pendidik dalam mengembangkan pembelajaran (Mujib, 2006).

Seorang pendidik yang memiliki kreativitas dan inovasi sangatlah penting untuk mengembangkan pembelajaran, karena sebaik apapun desain kurikulumnya namun jika dalam penyampaiannya kurang baik, tentu pembelajaran yang efektif tidak akan berjalan. Implementasi pembelajaran yang berbasis pendekatan saintifik dalam kurikulum pendidikan agama Islam adalah sebuah hal yang harus dilakukan untuk menghadapi segala hal yang dinamis dalam dunia pendidikan (Mohtar, 2017).

\section{Aksiologi Integrasi Sains dan Agama dalam Kurikulum PAI}

Agama Islam mengajarkan moral dan etika dalam berintegrasi dengan sains termasuk di dalamnya kurikulum PAI, maka dari itu secara aksiologi dapat memberikan hal baik terhadap etika pengembangan sains yang meliputi :

a. Sikap Ilmiah

Suatu sikap yang digunakan untuk mengetahui tentang bagaimana seorang individu mendapatkan sains yang bebas dari prasangka negatif dan dapat dipertanggungjawabkan dengan secara akademik. Sikap ilmiah yang harus dimiliki adalah tidak mempunyai rasa pamrih, bersikap selektif, memiliki rasa saling percaya, dan memiliki sikap yang etis.

b. Pemanfaatan Sains

Sains sangat memberikan manfaat pada manusia, namun pada sisi lainnya sains juga bisa memberikan dampak buruk jika salah dalam menggunakannya. Dalam menggunakan sains, sangat bergantung pada siapa dan apa latar belakang akademiknya. Oleh karena itu, siapapun yang ingin menggunakan sains hendaknya 
mereka para ilmuan yang telah memiliki landasan moral dan etika yang baik. Agama Islam dapat memberikan nilai-nilai yang etis terhadap pengembangan sains. Dengan adanya pendidikan agama Islam para pengembang sains diharapkan tidak melupakan apa yang telah dipelajarinya dan mengaplikasikannya dalam kehidupan. Akan tetapi diharapkan juga, sains yang dikembangkan oleh seorang ilmuan hendaknya saling berkesinambungan, sehingga dengan sains agama manusia dapat mengetahui kebenaran dan realitas tertinggi serta keterkaitannya dengan alam semesta dan lainnya.

\section{Pendidikan Agama Islam Era Digital}

Pendidikan sangat di perlukan guna membentuk karakater yang berkualitas dalam artian seseorang mempunyai karakter dengan akidah akhlak yang baik sehingga mampu menjadi contoh bagi orang di sekitarnya dalam agama islam sendiri menjunjung tinggi akan menuntut ilmu. Bahkan Allah Swt sendiri telah berfirman barang siapa yang menuntut ilmu maka akan di angkat derajatnya, oleh karena itu sebagai seorang muslim yang beriman dan bertakwa hendaknya kita menjalankan kewajiban yaitu dengan menuntut ilmu. Lahirnya seorang manusia awalnya dalam keadaan tidak tahu mengenai apapun, kemudian Allah memerintahkan kepada manusia untuk mencoba mencari tahu apa yang ada di sekitarnya serta mempelajari setiap perubahan yang terjadi dengan menggunakan panca indra. Dari sinilah terciptanya suatu sikap pantang dalam menghadapi sesuatu hambatan yang ada di depan.

Dalam pembelajaran dan pendidikan terdapat dampak yaitu lahirnya akhlak yang baik (Prasetya, 2015). Jika seseorang mempunyai niatan untuk memperdalam ilmu agama dari awalnya tidak tahu sama sekali kemudian di mempelajarinya di dalam sekolah yang berbasis agama, maka seiring berjalannya waktu akan mengerti tentang ilmu agama. Religion education merupakan pengertian dari pendidikan agama islam dalam bahasa inggris yang juga bisa diartikan merupakan suatu pendidikan yang mempunyai tujuan untuk menciptakan suatu orang orang beragama penekanan yang di ajarkan dalam agama islam tidak hanya dalam agama saja namun juga dalam hal attitude, aktivitas, kepercayaan hingga personal ideals (Ahyat, 2017)

Membahas mengenai attitude atau sikap maka tak lepas dari bahasan pendidikan agama Islam (Imam Wahyono, 2019). Didalam mata pelajaran ini di harapkan dapat membangun sikap yang baik bagi peserta didik karena di dalam alquran dan hadi sendiri telah menjelaskan banyak hal mengenai akhlak. Akhlak yang baik harus di terapkan 
diberbagai bidang kehidupan. Entah itu dalam hal bersosialisai, ibadah hingga dalam hal berwarga negara. Peran pendidikan agama islam dalam membangun karakakter bangsa antara lain:

a. Secara epistemologis, didalam islam komitmen tentang keilmuwan dijunjung tinggi karena menjadi sumber sebagai kekuatan dan kemajuan bangsa. Nabi Muhammad Saw menerima wahyu yang pertama yang berisikan tentang anjuran untuk membaca yang diartikan dengan pentingnya sebuah ilmu pengetahuan.

b. Dilihat dari segi sosiologis mayoritas masyarakat Indonesia yaitu beragama islam. Dalam hal ini PAI mempunyai sebuah tanggungan lebih besar untuk iku kontribusi dalam memajukan negeri ini. Dengan semangat islam yang mendasar maka akan mendorong pemeluknya untuk mengabdikan diri agar berguna bagi masyarakat, agama serta bangsa dengan etosnya sebagai manusia yang senantiasa bekerja keras dengan keikhlasan serta berfikiran dengan cerdas

c. Dilihat dari sejarah agama Islam telah memberikan banyak sumbangan dalam peradaban dunia. Seperti yang kita ketahui pada milenium pertama islam telah memunculkan tokoh tokoh dan filosof muslim sebagai sebuah ikon kemajuan peradaban Islam pada saat itu yang diakui oleh dunia sampai saat ini.

d. Sedangkan secara sosio-historis, agama islam sendiri merupakan sebuah lambang bagi bangsa Indonesia). Umat Islam di Indonesia memberikan sumabngan yang berarti dinilai sebagai berdiri dan tegaknya Negara Kesatuan Republik Indonesia (NKRI), dalam hal ini umat Islam Indonesia menghendaki Indonesia sebagai negara bangsa (nation state) bukan negara agama (teokrasi).

e. Terakhir PAI tentunya juga memiliki sebuah peranyang sangat penting di dalam perubahan nilai-nilai ajaran Islam yang menyegarkan juga bukan menyebar ketakutan ataupun semangat pesimistis serta membangun semangat optimistis.(Anwar, 2016).

Sebagai warga Negara Indonesia tentunya harus mempuyai sikap akan cinta tanah air, namun permasalahan yang terjadi pada genarasi muda di Indonesia adalah mengenai pendidikan karakter yang saat ini dirasa sangatlah mendesak. Gambaran terkait situasi masyarakat bahkan situasi dunia pendidikan di Indonesia menjadi motivasi pokok pendidikan karakter di Indonesia. Pendidikan karakter di Indonesia perlu pengembangan bila mengingat makin banyaknya tingkat tawuran yang dilakukan oleh pelajar, serta bentuk-bentuk kenakalan remaja lainnya terutama di kota-kota besar, 
pemerasan/kekerasan (bullying), kecenderungan dominasi senior terhadap yunior, penggunaan narkoba dan lain lain.

Masalah yang terjadi seperti di atas tentunya menjadi sebuah PR bagi kita yang merupakan bagian dari warga Negara Indonesia terutama generasi milenial dalam hal ini yang kebanyakan di tanyakan adalah mengenai pendidikan karakter yang ada di sekolah yaitu pembelajaran pendidikan agama islam. Oleh karena itu, pendidikan agama islam perlu di tingkatkan karena nyatanya banyak yang menganggap remeh pembelajaran agama islam padahal pendidikan agama islam sendiri mempunyai dampak yang besar bagi ahlak dan kepribadian. Lalu yang di pertanyakan disini adalah mengapa banyak yang menganggap remeh pembelajaran pendidikan agama islam ini? Banyak peneliti yang membahas kasus mengapa banyak siswa yang tidak sungguh-sungguh dalam mengikuti pembelajaran agama islam, ternyata banyak faktor yang menyebabkan siswa tidak bersungguh-sungguh dalam mengikuti pembelajaran pendididkan agama islam. Di antaranya dalah metode pendidikan yang monoton, kurangnya media pembelajaran hingga faktor internal dari diri siswa sendiri seperti kurangnya motivasi dari orang tua.

Kemanfaatan dari pembelajaran agama Islam mungkin belum langsung bisa dirasakan, namun akan terasa di masa depan. Khususnya ketika sudah mempunyai keluarga, pendidikan agama yang di dapat ketika bersekolah akan berguna untuk mendidik diri sendiri dan keluarganya kelak sehingga nantinya menjadi sebuah keluarga yang bahagia dunia hingga akhirat (M.Subkhan, 2019). Selain kemanfaatan dalam berkeluarga, juga dalam hal bermasyarakat akhlak yang dicerminkan akan menjadi pandangan di dalam hidup bermasyarakat. Selain itu juga sebagai perisai dalam menghadapi cobaan terutama dalam perkembangan zaman yang semakin beraneka ragam. Semua itu tidak akan berjalan dengan lancar apabila di dalam diri tidak tertanam kuatnya iman dan takwa. Karena dengan sebuah keimanan lah seseorang akan mempunyai keteguhan hati dan pendirian dalam mempertahankan dirinya dalam segala suatu kondisi dan situasi yang terjadi.

Pendidikan agama Islam sendiri sesungguhnya merupaka model dari penumbuhan generasi yang mempunyai iman, berhidmat kepada masyarakat, siap mengorbankan dirinya serta meberikan suatu kebahagiaan terhadap umat manusia yaitu telah menjalankan suatu peran penting menstranfer sebuah ilmu berupa nilai-nilai islam serta peradaban Islam dari generasi yang tua kepada generasi yang muda, ataupun dari generasi terdahulu ke generasi zaman sekarang. 
Perkembangan zaman yang semakin kompetetif menjadi tantangan bagi pendidikan Islam dan peradaban Islam oleh karena itu kedua-dua nya harus bersamasama menjadi sebuah kesatuan. Sebagai seorang muslim hendaknya sikap-sikap konsisten harus di terapkan dalam diri sendiri kelompok, masyarakat, bangsa hingga masuk kedalam pemerintah, sehingga dapat menunaikan amanat Islam sebagai mana yang telah Allah Swt amanat kan kepada umat manusia. Oleh karena itu, generasi muda harus melaksanakan apa yang menjadi kepentingan pendidikan agama islam dengan sesuai syariat, serta menanamkan akhlak yang mulia sebagai bentuk bekal menuju jalan yang di ridhoi Allah Swt bagi hambanya yang dengan keikhlasan belajar menuntut ilmu.

\section{Pembelajaran Sains berbasis Islam}

Pada kajian kali ini yang bertemakan tentang pembelajaran sains berbasis islam yang mana mana kajian ini lebih mengarah pada pembahasan kehidupan manusia yang saat ini telah mengalami penurunan dalam sisi keagamaan dan tertutupi oleh banyak ilmu pengetahuan, Sains dan teknologi saat ini telah merambat ke dalam kehidupan manusia akan tetapi tidak dengan dunia pendidikan dan pola pikir umat manusia. Sehingga sampai saat ini manusia khususnya umat islam banyak yang bertanya-tanya dalam memahami sains dan teknologi apakah termasuk dalam kategori pendidikan fard 'ayn atau fard kifāyah, baik dalam pemahaman teori maupun dalam bentuk praktik yang terjadi sekarang ini pada sekelompok manusia sekuler, sebuah filosofi yang menjiwai seluruh kurikulum pendidikan dimana agama diberi sedikit penekanan di luar pendidikan agama itu sendiri.

Tujuan dari kajian ini adalah agar pendidik dan peserta didik dalam proses pembelajaran sains dan teknologi tidak melepaskan eksistensi kekuasaan Allah Swt (Babuta, 2019). Dalam tiap materi sains yang dipelajari dan teknologi yang diterapkan mulai di sekolah-sekolah, perguruan tinggi dan masyarakat. Pendidikan Islam sebenarnya mampu menghapus idealisme sekuler yang tertanam dan berlaku dalam sistem pendidikan dewasa ini, serta memasukkan nilai-nilai ketuhanan secara komprehensif. Sekularisasi atau penerapan pengajaran yang mengharuskan agama dan pendidikans sains dan teknologi berbeda jalur sudah dibungkus sangat rapi oleh orang barat, Mereka juga memiliki pandangan lain yakni bahwa agama dapat mempengaruhi dari tinggkat kemajuan pendidikan. Oleh karena itu, mereka memiliki pemikiran bahwasanya agama dengan sains dan teknologi harus berdiri sendiri yaitu secara terpisah dimana ilmu 
pengetahuan alam untuk ilmu penegtahuan alam dengan menganut faham kebebasan nilai (value free). (Ishak, 2015)

Di Indonesia sendiri misalnya, sekularisme atau pembedaan antara pengajaran ilmu pengetahuan dan ilmu agama sangat terlihat jelas dengan adanya sistem pendidikan formal yakni pendidikan umum dan pendidikan agama yang sangat di prihatinkan lagi bahwa ada pendidikan ilmu agama diberikan presntasi yang sangat sedikit sedangkan porsi dari ilmu umum sangat banyak dan sangat jauh perbandingannya dengan ilmu agama. Hal ini ditakutkan dapat membuat kristalisasi sekularisme ilmu pengetahuan (science) dan pengetahuan agama.

Pengajaran di Indonesia juga mengalami sekularisasi internal dari kurikulum itu sendiri. Yang mana seperti kita lihat sekarang sistem pengajaran di hampir setiap sekoah telah diterapkan sistem pengajaran individual atau dalam artian pengajaran ilmu agama dan ilmu pengetahuan dibangun dari dua jalur yang berbeda tanpa ada rujukan dari agama islam terkecuali pada pelajaran kurikulum agama. Mata pelajaran tersebut merupakan inti ajaran Islam yang membahas tentang berbagai aspek keagamaan yang mempunyai hubungan langsung dengan kebutuhan hidup manusia didunia dalam hubungannya dengan Allah Swt. dan manusia dengan lingkungannya.

Iman dan tauhid atau ilahiyyah tidak boleh kita pisahkan dari sistem pendidikan dan seharusnya kedua hal tersebut menjadi acuan dalam masalah pembelajaran dikarenakan setiap apa-apa yang kita pelajari harus berdasarkan ketuhan yang kaitannya dengan iman dan kepercayaan baik suatu pemahaman yang besar ataupun yang kecil sekalipun itu, atau baik yang dipegangi secara kuat maupun yang dipahami secara samar. (Butt, 1996). Salah satu contohnya adalah air yang dijadikan sebagai sumber kehidupan mahluk hidup (Agustina, 2019). Dalam sains modern yang sekuler dikatakan bahwa air sebagai sumber daya alam yang berasal dari dalam tanah, gunung, sumur, hujan dan lainlain tanpa menjelaskan siapa yang mendatangkan air tersebut atau yang telah menjadikannya.

Disinilah seharusnya pengajar mampu menjelaskan lebih detail tentang eksistensi nilai iman dan takwa (IMTAK) dalam konteks sumber air tersebut yaitu bersumber dari Allah Swt. Demikian juga seharusnya dalam bidang sains dan teknologi yang harus didalamnya terkandung unsur ilahiyah dengan pemahaman iman dan taqwa. Semuanya bisa kita dapatkan al-Qur'an yang mana al-Qur'an adalah diciptakan atas dasar panduan ilahiyah. Di samping sebagai peta kehidupan, pegangan hidup dan inspirasi, Al-Qur'an 
yang merupakan samudra ilmu pengetahuan (sains) dan tersirat muatan-muatan teknologi yang tak bertepi. Tak akan habis mesti telah dikaji berabad abad lamanya dan yang seharusnya ilmunya di aflikasikan dalam kenyataan sains dan teknologi sepanjang masa.

Walaupun al-Qur'an bukan dari kitab ilmiah yang dapat disamakan dengan kitab ilmiah buatan manusia akan tetapi setiap apa-apa yang ada didalam kitab ilmiah buatan manusia semuanya pasti kandungannya telah ada dalam al-Qur'an, karena isi dari alQur'an sangatlah luas bahkan ada seorang syair arab yang mengumpamakan jika lautan sebagai tinta dan ranting sebagai penanya maka tidak akan sanggup menuliskan dari banyaknya ilmu allah swt. Pendekatan yang digunakan oleh al-Qur'an untuk mengungkapkan suatu kaedah ilmu pengetahuan amat berbeda dengan sebuah kajian ilmiah yang dilakukan oleh para saintis atau ilmuan.

\section{Kesimpulan}

Berdasarkan pemaparan data-data di atas, dapat disimpulkan bahwa pemahaman seorang individu dalam pendidikan agama Islam hendaknya perlu diulangi kembali agar dapat mencerminkan output yang sesungguhnya diinginkan oleh pembelajaran pendidikan agama Islam itu sendiri. Setidaknya melalui pembelajaran PAI dapat menghasilkan 2 (dua) aspek penting yakni: Pertama, menghasilkan output yang menjadi hamba dan wakil Allah SWT di muka bumi. Kedua, mendidik manusia untuk menjadi pelopor yang dapat menumbuh-kembangkan potensi dasar menuju kedewasaan intelektual. Pembelajaran sains merupakan pembelajaran yang bersifat umum dan wajib dilaksanakan di berbagai sekolah. Pembelajaran ini tidak lepas dengan alam semesta beserta isinya. Dimana hal tersebut berkaitan dengan penciptaan alam semesta beserta isinya yang semuanya itu merupakan ciptaan Allah Swt dan tidak ada selain Allah Swt yang mampu menandinginya. Antara ilmu pengetahuan alam dengan pendidikan agama islam merupakan segala sesuatu yang tidak dapat dipisahkan satu sama lain karena disetiap bahan ajar pasti terdapat dalam pendidikan agama islam yang tercantum dalam ayat suci al-Qur'an. Namun berbeda dengan orang barat yang menganggap bahwa antara ilmu pengetahuan alam dengan pendidikan agama islam tidak dapat diintegrasikan. Mereka menganggap bahwa suatu mata pelajaran haruslah berdiri sendiri secara terpisah dan kebebasan dalam berfikir menjadi tolak ukur dalam mempelajari ilmu pengetahuan alam. 


\section{Daftar Pustaka}

Agustina, S. M., Priyatna, O. S., \& Arif, S. (2019). Pengaruh Strategi Pembelajaran Aktif (Active Learning) Tipe Debat Aktif Terhadap Keaktifan Belajar Siswa dalam Mengikuti Pembelajaran Fiqih Kabupaten Bogor. Jurnal Mitra Pendidikan, 3 No 4.

Al Munawar, S. A. H. (2005), Aktualisasi Nilai-Nilai Qur'ani Dalam Sistem Pendidikan Islam (II). Ciputat: Ciputat Press.

Babuta Asma Is dan Abdul Rahmat. (2019). Peningkatan Kompetensi Pedagogik Guru Melalui Pelaksanaan Supervisi Klinis Dengan Teknik Kelompok. Al-Tanzim: Jurnal Manajemen Pendidikan Islam, Vol. 03, No. 01, 1-28.

Assegaf, Abd.Rachman. (2010), Pendidikan Islam Konstektual, Yogyakarta: Pustaka Pelajar.

C. W. Watson. (2005) Islamic Books and their Publishers: Notes on the Contemporary Indonesian Scene*, Journal of Islamic Studies, Volume 16, Issue 2, May, Pages 177-210.

Faturrahman, M. (2016), Pendidikan Karakter Dalam Perspektif Pendidikan Islam, Edukasi, 4(1), 1-25.

Ismail, S. (2013). Tinjauan Filosofis Pengembangan Fitrah Manusia dalam Pendidikan Islam. At-Ta'dib, 8(2), 242-263.

Julaiha, S. (2014). Implementasi Pendidikan Karakter Dalam Pembelajaran. Dinamika Ilmu, 14(2), 226-239.

Mujib, Abdul dan Jusuf Mudzakkir. (2006), Ilmu Pendidikan Islam, Jakarta: Kencana.

Mulyana, R. (2011), Mengartikulasikan Pendidikan Nilai, Bandung: Alfabeta

Muspiroh, N. (2016), Integrasi Nilai Islam Dalam Pembelajaran IPA ( Perspektif Pendidikan Islam). Jurnal Pendidikan Islam, 28(3), 484-498.

Prasetya, M. A. (2015). E-Learning Sebagai Sebuah Inovasi Metode Active Learning. Jurnal Penelitian Pendidikan Islam, 10(2).

Ridlwan, N. A. (2013). Konsep Pendidikan Karakter Dalam Perspektif Islam. Komunika, $7(1), 1-11$.

Respati, Y. A. (2018). Collaborative Learning Dalam Upaya Peningkatan Keaktifan Mahasiswa Pada Proses Pembelajran. Jurnal Efisiensi - Kajian Ilmu Administrasi, 15(2), 15-23.

Rojii, Mohamad, dkk. (2019). Desain Kurikulum Sekolah Islam Terpadu (Studi Kasus di SMP IT Insan Kamil Sidoarjo. Al-Tanzim: Jurnal Manejemen Pendidikan Islam Vol. 3 No. 2, 49-60.

Saufi, Ahmad dan Hambali. (2019). Menggagas Perencanaan Kurikulum Menuju Sekolah Unggul. Al-Tanzim: Jurnal Manajemen Pendidikan Islam Vol. 3, No. 2, 29-54.

Subekhan, M., \& Umyati, D. (2019). Pengaruh Metode Pembelajaran Talking Stick Terhadap Keaktifan Belajar Siswa Pada Mata Pelajaran Al-Qur'an dan Hadits. Jurnal Pendidikan Agama Islam, 6.

Supranoto, H. (2015). Implementasi Pendidikan Karakter Bangsa Dalam Pembelajaran, Ciputat: Logos

Uwes , Sanusi, (2003), Visi dan Pondasi Pendidikan (Dalam Perspektif Islam), Ciputat: Logos.

Wahyono, Imam. (2019). Mengembangkan Iklim Organisasi Di Sekolah dengan Menggunakan Model Tagiuri. Al-Tanzim: Jurnal Manajemen Pendidikan Islam, Vol. 03, No. 02, 61-72. 